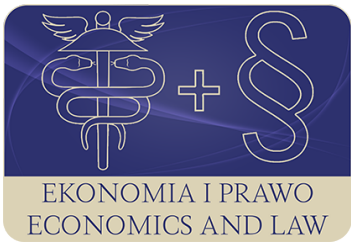

EKONOMIA I PRAWO. ECONOMICS AND LAW

Volume 17, Issue 3, September 2018

p-ISSN 1898-2255, e-ISSN 2392-1625

www.economicsandlaw.pl

ORIGINAL ARTICLE

received 02.01.2018; revised 04.05.2018; accepted 30.09.2018

Citation: Zajączkowska, M. (2018). The Energy Union and European Union energy security.

Ekonomia i Prawo. Ecomomics and Law, 17(3): 319-328.

doi:10.12775/EiP.2018.023.

\title{
The Energy Union and European Union energy security
}

\author{
MAGDALENA ZAJĄCZKOWSKA \\ Cracow University of Economics, Faculty of Economics and International Relations, Department \\ of European Economic Integration, ul. Rakowicka 27, 31-510 Cracow, Poland \\ $\square$ magdalena.zajaczkowska@uek.krakow.pl
}

\begin{abstract}
Motivation: The idea of EU Energy Union was presented in 2014 as a response to the deepening energy crisis with the main gas supply partner, Russia. In 2015
\end{abstract} and in 2017 European Commission presented the state of the Energy Union, which shows progress made since the Energy Union Framework Strategy was adopted. It was planned that in 2016 Energy Union would be fully implemented. The Energy Union is based on the three objectives of EU climate and energy policy: security of supply, sustainability and competitiveness. To reach these objectives the Energy Union focuses on five mutually supportive dimensions: 1) energy security, solidarity and trust; 2) a fully integrated European energy market; 3) energy efficiency contributing to moderation of demand; 4) decarbonising the economy and 5) research, innovation and competitiveness.

Aim: The objective of this article is to analyse the current state of the implementation of the first objective of the Energy Union: energy security, solidarity and trust in the context of the energy strategies of selected EU countries.

Results: None from the Member States was against the Energy Union project, but each of them understands this term differently. Full implementation of the concept is in contradiction with the energy policies of some Member States, mainly the big players. There are no concrete solutions to the implementation of instruments to enhance energy security.

Keywords: energy dependency; Energy Union; EU climate and energy policy; energy security JEL: All; E61; F50; H89 


\section{Introduction}

With the development of regional economic integration in Europe, action was taken between Member States to create a common energy policy and then climate and energy policy. Depending on the international situation in the world economy, the activities in the last century were of a different character. Due to the ongoing changes, especially in the external energy situation of the European Union, issues related to climate protection have become more and more frequently for decision-makers.

An analysis of the literature regarding energy security leads to the conclusion that more efforts to create a full theory of energy security are vital. This is due to a lack of knowledge in the generalization of energy security into clearly defined categories and precise definitions showing the mechanisms, principles and accuracy of processes and activities in this field. It can therefore be agreed that 'despite the many schools of thought energy security is rarely analyzed from a theoretical perspective' (Rewizorski et al., 2013, p. 72).

The idea of EU Energy Union was presented in 2014 as a response to the deepening energy crisis with the main gas supply partner, Russia. In 2015 and in 2017 European Commission (2015, 2017a, 2017b), presented the state of the Energy Union, which shows progress made since the Energy Union Framework Strategy was adopted. It was planned that in 2016 Energy Union would be fully implemented. The Energy Union is based on the three objectives of EU climate and energy policy: security of supply, sustainability and competitiveness. To reach these objectives the Energy Union focuses on five mutually supportive dimensions: 1) energy security, solidarity and trust; 2) a fully integrated European energy market; 3) energy efficiency contributing to moderation of demand; 4) decarbonising the economy and 5) research, innovation and competitiveness. The aim of the Energy Union is to ensure that European consumers - households and businesses - have secure, affordable, competitive and sustainable energy.

Latest data shows that the EU imported 53\% of its energy at a cost of around EUR 400 billion, which makes it the largest energy importer in the world. Six Member States depend on a single external supplier for their entire gas imports and therefore remain too vulnerable to supply shocks (European Commission, 2015).

Preliminary analysis of the above mentioned issues allows to put working thesis that full implementation of the Energy Union is in contradiction with the energy policies of some Member States, mainly the big players. There are no concrete solutions to the implementation of instruments to enhance energy security.

The following $7 \mathrm{EU}$ countries were chosen for the analysis: Czechia, Denmark, Germany, France, Lithuania, Poland and Great Britain. The criteria for choosing those countries is based on the energy dependency indicator, 
the changes that have taken place in this regard since 2008 and the level of autonomy in the creation of a national energy policy.

\section{Methods}

This article is an attempt to find answers to the following questions: What are the assumptions of the Energy Union?, How is the term energy security understood in literature on the subject and EU legislation?, How is the first dimension of the Energy Union realized in the European Union?, What kind of energy strategies are implemented by selected Member States?, Will the implementation of EU Energy Union increase the EU energy security?

To accomplish the objectives of the article, the analysis is divided into four parts. At the beginning, assumptions of the Energy Union have been presented. The second part describes selected definitions of energy security. The next part takes into consideration the implementation of the first dimension of the Energy Union: energy security, solidarity and trust. The last part is an attempt to describe the energy strategies of selected EU countries.

The analysis covers the period from 2008 (the beginning of the implementation of the climate and energy package) to 2014. The research tools used in the article include the study of literature to answer theoretical questions, descriptive analysis and comparative analysis to answer questions about the energy strategies.

\section{Assumptions of the Energy Union}

On 25 February 2015, the Commission adopted A framework strategy for a resilient Energy Union with a forward-looking climate change policy. The publication of that strategy created a new momentum to bring about the transition to a low-carbon, secure and competitive economy. In 2016 the vision of the Energy Union Framework Strategy was further translated into concrete legislative and non-legislative initiatives.

The Energy Union strategy has five mutually-reinforcing and closely interrelated dimensions designed to create greater energy security, sustainability and competitiveness (European Commission, 2015):

- energy security, solidarity and trust;

- a fully integrated European energy market;

- energy efficiency contributing to moderation of demand;

- decarbonising the economy;

- research, innovation and competitiveness.

In 2017 the European Commission(2017a) presented the Second report on the state of the Energy Union. The document presents the results of analysis of the implementation of the Energy Union, based on the methodology, which includes some key indicators relating to the five dimensions. According to the first dimension (energy security, solidarity and trust), the proposed indi- 
cators assessed progress on monitoring the relative dependency of the Member States and the EU as a whole on net imports of main energy carriers and on specific trade partners, and the overall reliability of the energy system (i.e. its overall ability to supply energy without interruption).

\section{Definition of energy security}

There is a wide range of energy security definitions introduced in literature on the subject. The main division in understanding the place of Energetics in the politics of modern countries is the separation of an economic-based approach from a politically-strategic (geopolitical) approach. Economists think that energy security as such is a myth and any potential dangers are associated with a shortage of fuels and disruptions in supply. They treat the markets as the main regulators of these issues. On the other hand, foreign policy analysts reason that energy security is a factor in national security and should therefore be studied from a political, as well an economic point of view (Kaczmarski, 2010, p. 13).

Based on a survey of 104 studies from 2001 to June 2014, it is found that the definition of energy security is contextual and dynamic in nature. The scope of energy security has also expanded, with a growing emphasis on dimensions such as environmental sustainability and energy efficiency. Significant differences among studies are observed in the way in which energy security indexes are framed and constructed. These variations introduce challenges in comparing the findings among studies (Ang et al., 2015). There is also a new evaluation technique based on the integrated application of subjective and objective weight allocation methods - SOWA (Subjective \& Objective Weight Allocation), which has introduced a balance score matrix (BSM) highlighting how well a country manages the trade-offs between the three competing dimensions for evaluating global national energy security (Wang \& Zhou, 2017, p. 19).

Energy security is also described as a one of the main targets of energy policy. It is hard to measure and difficult to balance against other policy objectives. The confusion about energy security is also reflected in political actions. But the common concept behind all energy security definitions is the absence of, protection from or adaptability to threats that are caused by or have an impact on the energy supply chain (Winzer, 2012).

In a very general sense, energy security can be described as a state in which there are no threats (Żukrowska, 2006, p. 21). Another definition identifies energy security as a 'dynamic process in which an important role is played by global and regional trends as well as specific actions in energy politics' (Pronińska, 2012, p. 55).

The definition contained in Polish law describes energy security as 'a state of the economy which makes it possible to cover the current and potential demand for recipients' fuel and energy needs in a technically and economically 
viable way, while maintaining environmental protection requirements' (Energy Law, 1997).

There are also definitions of energy security that describe it as "multidirectional activities (policies) of state and industry on a global and regional scale, whose goal is to ensure sufficient levels of available energy raw materials, especially oil and gas' (Chmielewski, 2009, p. 10).

A review of the literature on the subject leads to the conclusion that the most relevant group of definitions are those that take into account energy security in the context of a dynamic process involving many stakeholders. This process is related to the management of energy demand and supply and the energy needs of the entities primarily by ensuring the continuity of the energy supply.

\section{The Energy Union's first dimension: energy security}

In 2014 the European Commission set out in Energy Security Strategy how the EU would remain vulnerable to external energy shocks and has called on policy makers at national and EU level to reduce dependency on particular fuels, energy suppliers and routes. The Energy Union has been built on that strategy. It was underlined that the key drivers of energy security are the completion of the internal energy market and more efficient energy consumption. It depends on more transparency as well as on more solidarity and trust between the Member States (European Commission, 2017b).

The political challenges over the last years have shown that diversification of energy sources, suppliers and routes is crucial for ensuring secure and resilient energy supplies to European citizens and companies, who expect access to affordable and competitively priced energy at any given moment (European Commission, 2015).

Energy security, solidarity and trust is measured by European Commission by net import dependency (net import dependency-natural gas, net import dependency-crude oil and NGL, net import dependency-hard coal, nuclear imports and dependency), aggregate supplier concentration index (supplier concentration index-natural gas, supplier concentration index-crude oil and NGL, supplier concentration index-hard coal) and n-1 rule for gas infrastructure (European Commission, 2017a).

According to the European Commission's research on energy security, total net import dependency decreased between 2005 and 2014 in 22 Member States, indicating an improvement in energy security. Positive trends has been supported by increased indigenous renewable energy production (in e.g. Austria, Estonia, Ireland, Italy, Latvia, Portugal or Spain) and by decreasing the overall energy demand also due to energy efficiency improvements. Over the same period, total net import dependency significantly increased in a few countries, due to the decline of indigenous fossil fuel production (Denmark, Poland, United Kingdom) or the closure of nuclear plants (Lithuania) (European Commission, 2017a). 
There are only two net gas exporters in the EU: Denmark and the Netherlands. Net import dependency for gas has exceeded 90\% in 16 Member States, about half of which are fully reliant on imports (100\% net import dependency). Among all fuels, the EU's import dependency is the greatest for crude oil (increase from $81.3 \%$ in 2005 to $88.4 \%$ in 2014). The EU's net import dependency for hard coal was $55.7 \%$ in 2005 and rose to $67.9 \%$ by 2014 . Czechia is the only net exporter of hard coal in the EU. In 2014, even Poland, the EU's largest coal producer, became a marginal net importer. In 2015, 90 \% of the natural uranium included in fuel loaded in EU reactors came from outside the EU (European Commission, 2017a).

\section{The energy strategy of selected European Union countries}

The EU-28 dependency on energy imports increased from less than 40\% of gross energy consumption in the 1980s to 53.5\% in 2014; in 2008 it amounted to $54.7 \%$. The highest rates of energy dependency were recorded for crude oil (88.4\%) and natural gas (65.3\%). Over the last decade (between 2003 and 2013), EU dependency on non-EU deliveries increased faster in natural gas (by 13.3 pp) than in oil (by 9.9 pp) and solid fuels (9.2 pp). Since 2004, the net import of energy to the EU-28 has been greater than its primary production; in other words, net imports cover more than half of the gross domestic energy consumption in the EU-28 (Eurostat, 2016).

Taking into consideration the energy dependency of individual countries, the changes that have taken place in this regard since 2008 and the level of autonomy in the creation of a national energy policy, the energy strategies of the following $7 \mathrm{EU}$ countries were analyzed: Czechia, Denmark, Germany, France, Lithuania, Poland and Great Britain.

Each of these countries has undertaken activities that have created their own energy policy and at the same time, by virtue of their role in the European Union, have actively influenced the shape of the European Union's climate and energy policy. Poland has dominated, as one of the highest in the European Union, in the use of fossil fuels. In Czechia, despite the significant share of fossil fuel resources in the energy balance, nuclear energy has been maintained and developed. In the case of Germany and Denmark, the development of renewable energy has played an important role. France has been dominated by the use of nuclear power, which has been completely abandoned in Lithuania in recent years. In the UK, however, it was decided to diversify energy resources and develop all of them.

Germany's energy policy, known as Energiewende (energy transformation), was launched in 2012, several months after the failure of the Fukushima power plant. The most important assumptions of this policy were (Szczerbowski, 2015, p. 10):

- the exclusion from operation of nuclear power plants by 2022;

- significant reduction of carbon dioxide emissions; 
- power system based on renewable energy sources.

By amending the law, it was assumed that the share of renewable energy in electricity production would systematically increase from around 20\% to around $50 \%$ by 2030 and by $80 \%$ in 2050 (Dena, 2014).

It was emphasized that a fundamental concern in the implementation of this new energy policy was to ensure continuity of an energy supply following the phasing-out of subsequent nuclear power plants (Szczerbowski, 2015, p. 10). Ensuring the continuity of a supply would be through the use of coal and natural gas, which is a low-carbon raw material, and allows for the reduction of carbon dioxide emissions.

It has been estimated that the scope of changes in Germany's energy policy has been one of the most extreme in comparison to the rest of the EU Member States.

The UK energy sector reform began in 2012. It has been estimated that in its new energy policy, the United Kingdom has been moving away from a market model towards greater state intervention in energy market processes (Szczerbowski, 2015, pp. 10-11). Government priorities have been the diversification of energy supply and a reduction in the country's energy dependency (Department of Energy and Climate Change, 2012; 2013). At present, the UK's energy mix is based primarily on fossil fuels, which makes their activities particularly important. Energy from crude oil and petroleum products accounts for 36\% of the country's energy mix, natural gas supplies for $31 \%$ of the country's needs, and coal for $16 \%$. There are also fears of over-exploiting productive assets, which may reduce the country's energy security. It has been assumed that by 2020, one fifth of the power plants will be closed, a large proportion of which will be unstable generation (wind energy and photovoltaics) or inflexible supply (nuclear power). In addition, the UK is a leader in the development of wind energy, especially in maritime wind farms (Kaliski et al., 2011).

The basis of France's energy system is to continue to be nuclear power, which was confirmed in 2014 in the country's latest energy policy. The 2012 assumptions assumed a gradual reduction of nuclear power units from more than $73 \%$ of electricity generated to $50 \%$ by 2025 . France is planning a gradual decline in the share of nuclear power in the country's energy mix to be replaced by renewable energy (development of photovoltaic and wind power plants) (Szczerbowski, 2015, s. 11).

In Denmark, the country's energy strategy, which proposes complete abandonment of fossil fuels by 2050, are primarily to introduce offshore wind farms in order to increase the proportion of renewable energy. This is a completely innovative approach towards energy policy in the world. It has been planned that by 2020, one third of the energy produced in Denmark will come from renewable energy resources. By 2030, a complete departure from fossil fuels in the production of electricity has been proposed (Szczerbowski, 2015, p. 11).

A different approach to the shape of energy policy has been proposed in Czechia. The further use of coal, primarily brown coal, with the addition 
of nuclear power and diversification to other resources has been proposed. Basic assumptions were presented in 2011. In 2013, the implementation of a longterm energy strategy with a view to 2040 was launched. In 2014, nuclear power plants accounted for about $20 \%$ of installed capacity and accounted for over $35 \%$ of electricity produced. It has been planned that nuclear power will account for $49-58 \%$ of the total electricity production by 2040 . In addition, the share of coal in electricity production will be reduced from the current $38 \%$ to around 20\% (Eurostat, 2016; Szczerbowski, 2015, p. 11).

In 2015, the proposal for the Polish Energy Policy up until 2050 were presented, which replaced the previously binding Polish Energy Policy until 2030 (Ministry of Energy, 2016). It has been assumed that the primary sources of energy will still be native hard coal resources, which will help maintain the country's energy independence (Gawlik et al., 2016, p. 347). Based on the research, it has also been shown that in terms of energy security, the most stable transition was reported in Hungary and Poland (Radovanović et al., 2017, p. 1020). It has also planned the inclusion of nuclear power in Poland's energy mix and further development of the renewable energy sector.

In 2016, the Lithuanian government presented the proposal of the country's new energy strategy, which is partly in line with those presented in 2010 (achieving energy independence, enhancing the country's broadly defined economy, developing renewable energy sources) (Wyganowski, 2010, p. 1). Currently, the Lithuanian Ministry of Energy plans to achieve energy independence through the implementation of the Nord Barlt2 project by 2025 and a merger with Poland - LitPol Link 2. Moreover, it was decided to abandon the use of nuclear power in the country's energy mantle and to suspend the nuclear power plant project Visaginas because of economic unprofitability. In addition, the strategy indicated the necessity of carrying out Baltic Sea research on the development of offshore wind farms. It has also been planned that by $203035 \%$ of Lithuanian energy will come from renewable sources and up to $70 \%$ by 2050 (CIRE, 2016).

\section{Results}

None from the Member States was against the Energy Union project, but each of them understands this term differently. Full implementation of the concept is in contradiction with the energy policies of some Member States, mainly the big players. There are no concrete solutions to the implementation of instruments to enhance energy security.

\section{Conclusion}

Countries with relatively low levels of raw materials and energy import dependency (Czechia, Poland, Romania, Denmark, Estonia) base their energy balance on their natural fossil fuels or on renewable resources. In Poland, fossil fuels 
account for 52\% of the country's energy mix. In Estonia it is as much as 66\% and in the Czechia 38\%. In Romania, 17\% of the country's energy mix is based on fossil fuels, but renewable energy is already responsible for $19 \%$ of its energy mix. In Denmark, dominates energy from renewable resources - 26\% in the country's energy balance (Eurostat, 2016).

The analysis leads to the conclusion that more and more EU countries are pursuing energy policy primarily based on their national policies, which are not always coherent with the EU Energy Union project. This is due to the existing divergences of the socio-economic interests of individual Member States. This results in the adoption of national energy policies, and therefore makes the attempt to reach a consensus often impossible.

According to the changes taking place in the European Union and in the international situation, it is to be expected that in the long term further diversification of national energy policies based on national interest will occur and not for the interest of the whole European Union.

There is therefore a need to make progress towards solidarity between Member States, especially in the event of an energy crisis or an energy supply disruptions.

\section{References}

Ang, S.W., Choong, W.L., \& Ng, T.S. (2015). Energy security: definitions, dimensions and indexes. Renewable \& Sustainable Energy Reviews, 42. doi:10.1016/j.rser.2014.10.064.

Chmielewski, A. (2009). Bezpieczeństwo energetyczne państwa. Geopolityczne uwarunkowania. Warszawa: MM.

CIRE. (2016). Nowa strategia energetyczna Litwy: nadzieje na wspótpracę Polski. Retrieved 30.03.2017 from http://www.cire.pl.

Dena. (2014). Retrieved 20.02.2017 from https://www.dena.de.

Department of Energy and Climate Change. (2012). Energy security strategy. Retrieved 01.02.2017 from https://www.gov.uk.

Department of Energy and Climate Change. (2013). Electricity market reform. Retrieved 01.02.2017 from https://www.gov.uk.

European Commission. (2015). Energy Union package. Retrieved 25.04.2017 from https://ec.europa.eu.

European Commission. (2017a). Second report on the state of the Energy Union. Retrieved 25.04.2017 from https://ec.europa.eu.

European Commission. (2017b). The Energy Union's five dimensions: policy observations at member state and EU level. Retrieved 25.04.2017 from https:// ec.europa.eu.

Eurostat. (2016). Energy dependency. Retrieved 01.04.2017 from http://ec.europa.eu/eurostat. 
Gawlik, L., Kaliski, M., Kamiński, J., Sikora, A.P., \& Szurlej, A. (2016). Hard coal in the fuel-mix of Poland: the long-term perspective. Archives of mining sciences, (61)2. doi:10.1515/amsc-2016-0025.

Kaczmarski, M. (2010). Bezpieczeństwo energetyczne Unii Europejskiej. Warszawa: Wydawnictwa Akademickie i Profesjonalne.

Kaliski, M., Frączek, P., \& Szurlej, A. (2011). Brytyjskie doświadczenia a zmiana struktury źródeł energii w Polsce. Polityka Energetyczna — Energy Policy Journal, 14(2).

Ministry of Energy. (2016). Retrieved 15.04.2017 http://www.me.gov.pl.

Pronińska, K. (2012). Bezpieczeństwo energetyczne Unii Europejskiej w warunkach kryzysu finansowego. In K.M. Księżpolski, \& K. Pronińska (Eds.), Bezpieczeństwo ekonomiczne w perspektywie politologicznej: wybrane problemy. Warszawa: Elipsa.

Radovanović, M., Filipović, S., \& Pavlović, D. (2017). Energy security measurement: a sustainable approach. Renewable and Sustainable Energy Reviews, 68. doi:10.1016/j.rser.2016.02.010.

Rewizorski, M., Rosicki, R., \& Ostant, W. (2013). Wybrane aspekty bezpieczeństwa energetycznego Unii Europejskiej. Warszawa: Difin.

Szczerbowski, R. (2015). Polityka energetyczna wybranych krajów europejskich a strategia energetyczna Polski. Polityka energetyczna - Energy Policy Journal, 18(3).

Ustawa z dnia 10 kwietnia 1997 r. - Prawo energetyczne [Energy Law of April 10, 1997] (Dz.U. $1997 \mathrm{nr} 54$ poz. 348) (Poland).

Wang, Q., \& Zhou, K. (2017). A framework for evaluating global national energy security. Applied Energy, 188. doi:10.1016/j.apenergy.2016.11.116.

Winzer, C. (2012). Conceptualizing energy security. Energy Policy, 46. doi:10.1016/j.enpol.2012.02.067.

Wyganowski, J. (2010). Na Litwie: Nowa (stara) strategia. Energia Gigawat, 11.

Żukrowska, K. (2006). Pojęcie bezpieczeństwa i jego ewolucja. In K. Żukrowska, \& M. Gracik (Eds.), Bezpieczeństwo międzynarodowe. Teoria $i$ praktyka. Warszawa: SGH.

\section{Acknowledgements}

Author contributions: author has given an approval to the final version of the article.

Funding: this research was fully funded by the Cracow University of Economics.

Note: the results of this study were presented at 9th International Conference on Applied Economics Contemporary Issues in Economy (June 22-23, Torun, Poland). 